\title{
Acceleration of wound healing by topical application of gel \\ formulation of Barringtonia racemosa (L.) Spreng kernel
}

\section{extract [version 1; peer review: 2 approved with reservations]}

\author{
Nur A. Sitohang1,2, Effendy D. L. Putra³, Hajjul Kamil4, Musri Musman (iD) \\ ${ }^{1}$ Graduate School of Mathematics and Applied Science, Universitas Syiah Kuala, Banda Aceh, 23111, Indonesia \\ ${ }^{2}$ Faculty of Nursing, Universitas Sumatera Utara, Medan, 20222, Indonesia \\ ${ }^{3}$ Faculty of Pharmacy, Universitas Sumatera Utara, Medan, 20222, Indonesia \\ ${ }^{4}$ Faculty of Nursing, Universitas Syiah Kuala, Banda Aceh, 23111, Indonesia \\ ${ }^{5}$ Faculty of Education and Teachers' Training, Universitas Syiah Kuala, Banda Aceh, 23111, Indonesia
}

V1 First published: 15 Feb 2022, 11:191

https://doi.org/10.12688/f1000research.104602.1

Latest published: 16 Mar 2022, 11:191

https://doi.org/10.12688/f1000research.104602.2

\section{Abstract}

Background: Phytomedicines are gaining a spotlight in wound management, where much research has suggested the wound healing potential of Barringtonia racemosa. The objective of this study was to investigate the effectiveness of $B$. racemosa kernel extract in accelerating wound healing process in animal models.

Methods: $B$. racemosa kernel was extracted using ethanol:water (7:3) solvent and was then used as a bioactive ingredient in a Carbopol 940based gel formulation in four different concentrations (1, 3, 5 and 7 ppm). A $3 \mathrm{~cm}$ diameter wound was made in the dorsal area of Rattus norvegicus rat and wound healing process was assessed up to 12 days using DESIGN (Depth, Exudate, Size of Inflammation/Infection, Granulation tissue, and Necrotic tissue) scoring system.

Results: Our data suggested that the DESIGN scores were significantly different among concentration groups after the $3^{\text {rd }}$ day onward suggesting $B$. racemosa extract accelerated the wound healing process. Rats treated with gel formulation containing $7 \mathrm{ppm}$ of $B$. racemosa kernel extract had faster wound healing than that treated with topical Metcovazin.

Conclusion: $B$. racemosa kernel extract was effective in accelerating wound healing on rats. Further study is warranted to purify the bioactive component and the action mechanism in wound healing process.

Keywords

Barringtonia, Gel, Lecythidaceae, Phytomedicine, Wound healing

\section{Open Peer Review Approval Status \\ 1 \\ 2 \\ version 2 \\ (revision) \\ 16 Mar 2022 \\ version 1 \\ $15 \mathrm{Feb} 2022$

$\begin{array}{cc} & \\ \text { view } & \text { view } \\ ? & ? \\ \text { view } & \text { view }\end{array}$ \\ 1. Talha Bin Emran ID, BGC Trust University Bangladesh, Chittagong, Bangladesh \\ 2. Trina Ekawati Tallei ID, Sam Ratulangi \\ University, Manado, Indonesia \\ Any reports and responses or comments on the article can be found at the end of the article.}


This article is included in the Plant Science

gateway.

Corresponding author: Musri Musman (musrimusman@unsyiah.ac.id)

Author roles: Sitohang NA: Conceptualization, Data Curation, Formal Analysis, Funding Acquisition, Investigation, Methodology, Project Administration, Resources, Validation, Writing - Original Draft Preparation, Writing - Review \& Editing; Putra EDL: Investigation, Resources, Supervision, Writing - Review \& Editing; Kamil H: Methodology, Supervision, Validation, Writing - Review \& Editing; Musman M: Conceptualization, Resources, Supervision, Validation, Writing - Original Draft Preparation, Writing - Review \& Editing

Competing interests: No competing interests were disclosed.

Grant information: This research was financially supported by the USU's Research Center under the TALENTA scheme (No. 439/UN5.2.3.1/PPM/KP-TALENTA USU/2019) April 1, 2019.

The funders had no role in study design, data collection and analysis, decision to publish, or preparation of the manuscript.

Copyright: ( 2022 Sitohang NA et al. This is an open access article distributed under the terms of the Creative Commons Attribution License, which permits unrestricted use, distribution, and reproduction in any medium, provided the original work is properly cited.

How to cite this article: Sitohang NA, Putra EDL, Kamil H and Musman M. Acceleration of wound healing by topical application of gel formulation of Barringtonia racemosa (L.) Spreng kernel extract [version 1; peer review: 2 approved with reservations] F1000Research 2022, 11:191 https://doi.org/10.12688/f1000research.104602.1

First published: 15 Feb 2022, 11:191 https://doi.org/10.12688/f1000research.104602.1 


\section{Introduction}

Wounds may occur on skin because of external or internal stimuli including that of physical, chemical, electrical, or thermal. Injured skin loses its function, causing it to be unable to protect the body from the entry of pathogenic organisms. ${ }^{1,2}$ Wound healing could be initiated rapidly owing to body's hemostasis system. Overlapping, yet distinctive, stages of wound healing are inflammation, proliferation, and remodeling. ${ }^{3}$ Of which, inflammation is the most crucial phase that occurs to protect the wound from bacterial infection and promoting tissue repair. ${ }^{3,4}$ Therefore, many researches focused on improving wound management in particular during the inflammation stage. ${ }^{5}$ Several traditional medicines have been used in wound dressing to accelerate the healing process, including those consisting of plant extracts. ${ }^{6,7}$

Emerging research has tried to provide evidence-based phytomedicines as a candidate to treat diseases including as substitute or addendum in wound management. ${ }^{8-10}$ There have been many examples of plant-based traditional medicines possessing wound healing properties. ${ }^{9,10}$ This could be attributed to the high content of bioactive compounds in plant extract such as saponins, flavonoids, terpenoids, and tannins. ${ }^{6,11}$ Barringtonia racemosa (L.) Spreng is among commonly used plants in ethnomedicine which has been reported to contain diterpenes, triterpenoids, flavonoids, steroids and saponins. ${ }^{12}$ A previous phytochemical screening reported that extracts from kernels, barks, and stems of B. racemosa contained a rich amount of saponins. ${ }^{13}$ Furthermore B. racemosa extract has been reported to be active against Grampositive and -negative bacteria such as Staphylococcus aureus, Staphylococcus epidermidis, Eschericia coli, Shigella dysentriae, Vibrio cholerae and Proteus sp. ${ }^{14}$ Its potential as a wound healing therapy was further corroborated by the studies reporting antinociceptive (analgesic), antioxidant, anti-inflammatory, and anti-fungal properties of $B$. racemosa extracts. $^{14,15}$

Current research has not reported B. racemosa extract's potential in wound healing. Indeed, there are studies that have employed plant extracts from the same family (Lecythidaceae) ${ }^{16}$ or the same genus (Barringtonia). ${ }^{17}$ Although the phytochemical constituents might be similar across plants in the same family or genus, differences still expected between species. ${ }^{18}$ Currently, there are no studies reporting in-vivo investigation of wound healing potential of $B$. racemosa extract. This study sought to investigate the wound healing effect of $B$. racemosa extract in an animal model. Several animals have been used to study the wound healing processes including to evaluate efficacy of different treatment modalities. ${ }^{19}$ However, rats have been widely used in the study of skin wound healing because of their availability, low cost, and small size. ${ }^{20}$ Studies have used rats as an animal model to evaluate the effect of several natural extracts on would healing. ${ }^{21-24}$ The kernel was used since most of secondary metabolites stored in the kernel act as a surviving mechanism of the plant. ${ }^{25}$ After the extract was obtained, the gel formulation was made with beneficial characteristics for wound healing including high content of water, flexibility and biocompability. ${ }^{26}$ The prepared formulation was then used to treat the wound in animal models.

\section{Methods}

Ethics

The protocol of this study was approved by the Ethics Committee of the Faculty of Mathematics and Natural Sciences, Universitas Sumatera Utara, Indonesia (\#0700/KEPH-FMIPA/2019). All efforts were made to ameliorate the suffering of the rats; criteria (described below) were established to ensure that any subjects could be excluded if need be. After the experiment, all animals were returned to the breeding center of Pharmacology Laboratory at Faculty of Pharmacology, Universitas Sumatra Utara.

\section{Materials}

Materials used in this research were pharmaceutical grade chemicals including ethanol $96 \%$, Carbopol 940, triethylamine, propylene glycol, and methyl paraben (Merck, Selangor, Malaysia). Ripe fruits of B. racemosa (L.) Spreng were collected from Desa Gampong Pulo, Bireuen Regency, Aceh, Indonesia.

\section{Study design}

The study was conducted in the Pharmacy Laboratory of Faculty of Pharmacy, Universitas Sumatera Utara, Medan, Indonesia. The wound healing effect of gel formulation of B. racemosa extract was assessed in rat models (Rattus norvegicus) and the wound healing process was assessed using DESIGN scoring system (Depth, Exudate, Size of Inflammation/Infection, Granulation tissue, and Necrotic tissue).

\section{B. racemosa kernel extraction study design}

The white colored kernels of $B$. racemosa were taken from the fruits, washed repeatedly using water, and sun-dried. Dried kernels were cut into pieces with $1 \mathrm{~cm}$ in diameter, oven-dried at $40^{\circ} \mathrm{C}$, and crushed into powder using a DF-15 grinder (Cgoldenwall) before sifted through a 60-mesh sieve. Maceration was then conducted on the $B$. racemosa kernel powder in a ethanol:water (7:3) solvent for 24 hours. This process was repeated until the solvent turned colorless. The produced 
filtrate was concentrated using a Hei-VAP Expert rotary evaporator (Heidolph Instruments GmbH \& CO. KG, Schwabach, Germany) for 30 minutes.

\section{Gel preparation}

Gel formulation was prepared using Carbopol 940, triethylamine, propylene glycol, methyl paraben, and distilled water. Briefly, $0.2 \mathrm{~g}$ methyl paraben $(0.2 \% \mathrm{w} / \mathrm{w})$ was dissolved in $100 \mathrm{~mL}$ pre-heated distilled water $\left(70^{\circ} \mathrm{C}\right)$, and then added with $2 \mathrm{~g}$ Carbopol 940 to form the gel. The mixture was stirred by hand until foam and gel were formed. Subsequently, $6 \mathrm{~g}$ propylene glycol $(6 \% \mathrm{w} / \mathrm{w})$ and $2 \mathrm{~g}$ triethylamine $(2 \% \mathrm{w} / \mathrm{w})$ were added into the gel solution. Lastly, B. racemosa kernel was added to gel formulation with a concentration of $1,3,5$, and $7 \mathrm{ppm}(\mathrm{mg} / \mathrm{kg})$. The B. racemosa fruits and prepared gel formulation are presented in Figure 1.

\section{Animal model}

A total of 24 male rats (Rattus norvegicus) Wistar strain with average body weight (200-300 g) and age of 2-3 months old were acclimated and fed ad libitum with standardized feed $\left(\right.$ RatBio $\left.{ }^{\circledR}\right)$. This animal model has been used to assess the effects of some drugs on wound healing process. ${ }^{27,28}$ All conditions (i.e., temperature, humidity and lighting) followed the guideline from Institute for Laboratory Animal Research, USA. ${ }^{29}$ The acclimatization process was conducted for a week prior to the study under laboratory conditions with $60 \%$ humidity, temperature $23 \pm 1{ }^{\circ} \mathrm{C}$, and $12 \mathrm{~h}$ light-dark cycle. Afterward, the 24 rats were randomly divided into six groups of four; a negative control, a positive control, and four treatment groups based on the Federer formula. ${ }^{30}$ The mathematical expression of Federer formula is shown below:

$$
(\mathrm{t}-1)(\mathrm{n}-1)>15
$$

Where $\mathrm{t}$ and $\mathrm{n}$ are number of group and number of subjects in a group, respectively. As for the randomization, it was performed on an online web-based randomizer tool (https://www.randomizer.org/).

The same laboratory conditions of acclimatization (i.e., $60 \%$ humidity, temperature $23 \pm 1{ }^{\circ} \mathrm{C}$, and $12 \mathrm{~h}$ light-dark cycle) were used during the actual study.

\section{B. racemosa gel application}

Dorsal area of the rats was shaved with a diameter of $3 \mathrm{~cm}$ around the incision area. Prior to incision, the skin was disinfected using rubbing alcohol $70 \%$ and the rats were anesthetized using intramuscular injection of ketamine and xylazine ( $75 \mathrm{mg} / \mathrm{kg}$ body weight). A skin incision was made with a wound length of $2 \mathrm{~cm}$ and a depth of $0.2 \mathrm{~cm}$ to the dermis, as suggested previously. ${ }^{16,17}$ Each treatment group received $100 \mathrm{mg}$ gel formulation with $B$. racemosa kernel extract of 1 ppm, 3 ppm, 5 ppm, and 7 ppm each. The study was controlled by positive and negative control groups.

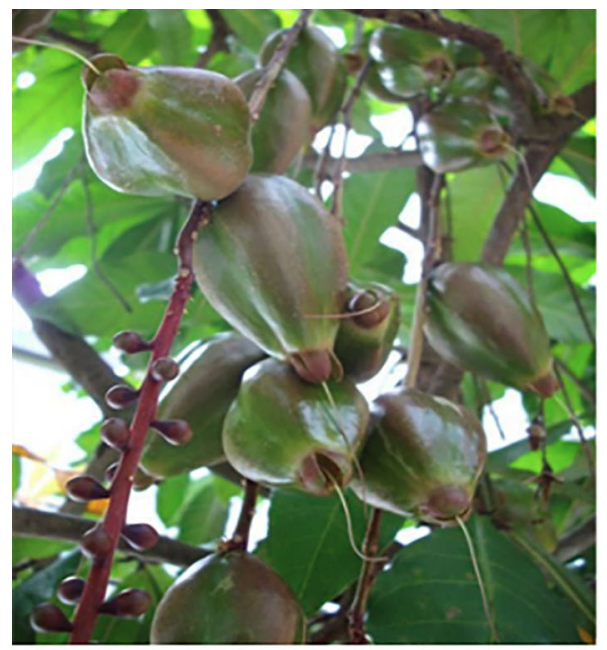

(a)

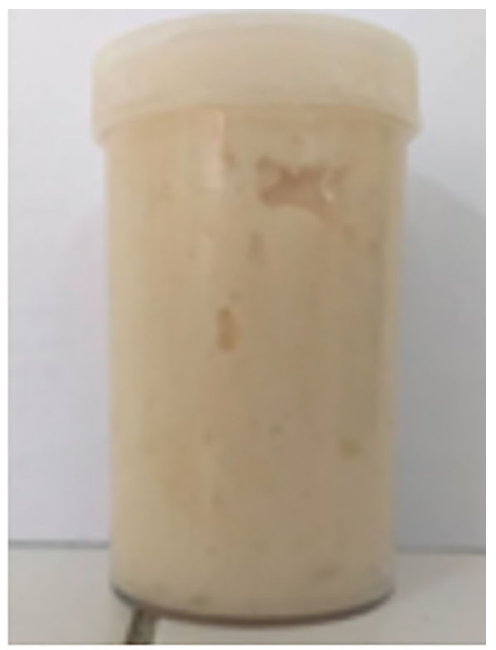

(b)

Figure 1. (a) Barringtonia racemosa (L.) Spreng and (b) its ethanolic extract gel. 
Negative control was not administered any treatment, and the positive control was smeared with $100 \mathrm{mg}$ of $25 \mathrm{~g}$ Metcovazin cream consisting of zinc oxide and chitosan.

\section{Assessment of healing process}

The wound healing process was observed once daily for 12 days and recorded based on DESIGN scores. Detailed components assessed in DESIGN scoring system could be seen as follows: depth (0-5), exudate (0-6), wound area (0-15), infection (0-9), granulation (0-6), necrotic (0-6), and pocket (0-24). For each animal, the DESIGN scores were summed to give a single score (ranging from 0 to 71); the lower the score better the healing process. The data were presented descriptively in mean \pm standard deviation. In each observation, the body weight of the animals and the behavior were observed. Rapid weight loss of $15 \%$ and abnormal behaviors such as apathy or increased aggression were set as humane endpoints to exclude the animal from the study. After the study completion, all animals were returned to the breeding center of Pharmacology Laboratory at Faculty of Pharmacology, Universitas Sumatra Utara.

\section{Statistical analysis}

Kolmogorov-Smirnov test was employed to assess the normality of the data distribution. Kruskal-Wallis test was used to compare DESIGN scores obtained from different groups on the same observation day. Meanwhile, Mann-Whitney test was used to compare data from two different groups collected on the same day. All analyses were conducted on GraphPad Prism 9.2.0 software (GraphPad Software, San Diego, CA, USA) or free alternatives such as JASP or SOFA Statistics could be used.

\section{Results}

Wound healing effect of $B$. racemosa extract gel

Periodical changes of DESIGN scores observed in the rats are presented in Table 1. Negative control had a gradual reduction of DESIGN score but still persisted even after 12 days. Similar results were also observed in the treatment group with $B$. racemosa 1 ppm extract concentration. When the extract concentration in gel formulation was increased to 3 or $5 \mathrm{ppm}$, the wound resolved after 12 days of observation. The results were similar to that obtained in positive control which received commercial wound healing cream - Metcovazin. Interestingly, B. racemosa extract with a concentration of $7 \mathrm{ppm}$ could perform better wound healing on the rat models; this condition yielded 0 DESIGN score on the $11^{\text {th }}$ day. DESIGN scores, observed from day 3 to day 12, between studied groups had statistical significance $(p<0.001)$ suggesting the extract could effectively accelerate the wound healing process. On day 11, the DESIGN scores were significantly different between $7 \mathrm{ppm}$ group and positive control group ( $p=0.0286$, Mann-Whitney test) suggesting that $B$. racemosa extract with a concentration of $7 \mathrm{ppm}$ in gel formulation could assist better wound healing than Metcovazin.

\section{Macroscopic observation of treatment}

During the first 3 days of treatment, all groups have entered inflammatory phase characterized by the presence of fluids, lesion area of $<4 \mathrm{~cm}^{2}$, redness, and swelling (Figure 2). Thereafter, rats underwent proliferation phase indicated by light exudate, lesion area of $<3 \mathrm{~cm}^{2}$, redness and healthy granulation of $<10 \%$. In general, the proliferation phase could be observed lasted until the $9^{\text {th }}$ day. Faster wound healing process could be found in a group treated with 7 ppm $B$. racemosa extract, where on the $6^{\text {th }}$ day, the wound had persistent redness, less than $3 \mathrm{~cm}^{2}$ lesion area, and $80 \%$ healthy granulation without the presence of exudate and redness (Figure 2).

Table 1. DESIGN score recorded for 12 days of $B$. racemosa extract gel treatment.

\begin{tabular}{|l|l|l|l|l|l|l|}
\hline \multirow{2}{*}{ Group } & \multicolumn{2}{|l|}{ DESIGN mean score \pm SD } & & & \\
\hline Negative control & Day 0 & Day 3 & Day 6 & Day 9 & Day 11 & Day 12 \\
\hline 1 ppm & $15 \pm 0.00$ & $13 \pm 0.00$ & $11.5 \pm 1.00$ & $8 \pm 2.00$ & $3.5 \pm 1.73$ & $2.25 \pm 1.89$ \\
\hline 3 ppm & $15 \pm 0.00$ & $12 \pm 0.00$ & $10 \pm 0.00$ & $9 \pm 0.00$ & $5 \pm 0.00$ & $2 \pm 0.00$ \\
\hline 5 ppm & $15 \pm 0.00$ & $12 \pm 0.00$ & $10 \pm 0.00$ & $5 \pm 0.00$ & $2 \pm 0.00$ & $0 \pm 0.00$ \\
\hline 7 ppm & $15 \pm 0.00$ & $12 \pm 0.00$ & $10 \pm 0.00$ & $5 \pm 0.00$ & $2 \pm 0.00$ & $0 \pm 0.00$ \\
\hline Positive control & $15 \pm 0.00$ & $10 \pm 0.00$ & $9 \pm 0.00$ & $2 \pm 0.00$ & $0 \pm 0.00$ & $0 \pm 0.00$ \\
\hline p-value* & $15 \pm 0.00$ & $10 \pm 0.00$ & $9 \pm 0.00$ & $5 \pm 0.00$ & $1.5 \pm 0.58$ & $0 \pm 0.00$ \\
\hline & NA & $0.0003^{*}$ & $0.0006^{*}$ & $0.0008^{*}$ & $0.0013^{*}$ & $0.0005^{*}$ \\
\hline
\end{tabular}

Positive control group received Metcovazin cream. NA: not applicable.

*Significant at $p<0.001$ based on Kruskal-Wallis test. 

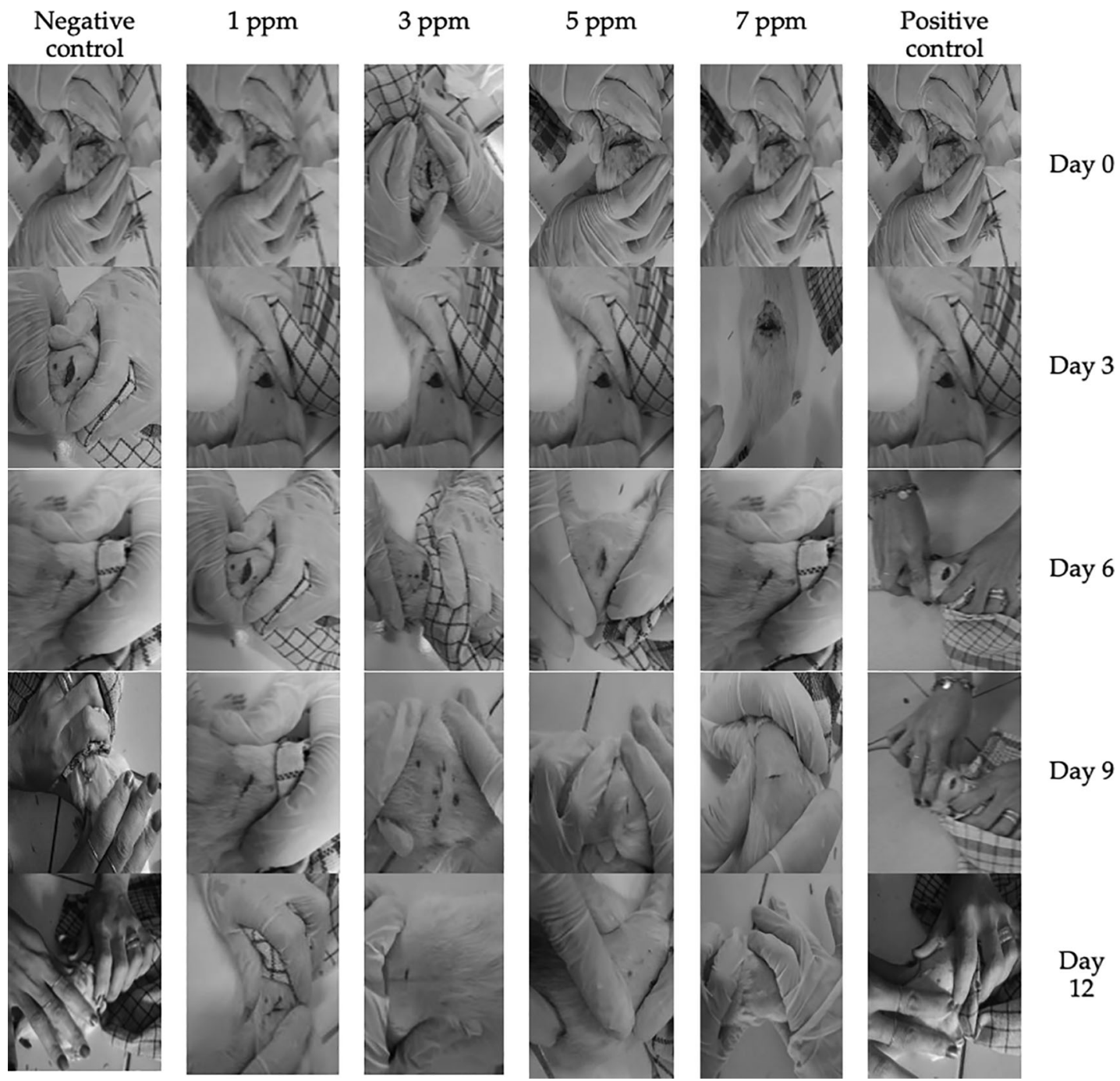

Figure 2. Wound healing process in rats after the treatment using B. racemosa extract gel. Positive control group received Metcovazin cream.

After 12 days of observation, most of the wounds had reached remodeling phase. There were two rats in negative control group that experienced remodeling phase accompanied with persistent redness and healthy granulation ( $>90 \%)$, where no exudate, wounded area, and signs of inflammation (Figure 2). However, the two other rats in the negative control group still had $4 \mathrm{~cm}^{2}$ lesion. In all animals within $1 \mathrm{ppm}$ of $B$. racemosa extract, the wound persisted with an area of less than $4 \mathrm{~cm}^{2}$ with no sign of infection and $95 \%$ of the wound had healthy granulation. When the concentration was increased to 3 or $5 \mathrm{ppm}$, the wounds were completely closed with granulation reaching $90 \%$ or more. Similar results were also obtained in the positive group. The fastest wound healing was found in treatment group receiving gel containing $7 \mathrm{ppm}$ B. racemosa extract, where wound area and granulation were no longer observable (Figure 2).

\section{Discussion}

Wound healing is a complex dynamic process in the restoration of tissue anatomy function after injury. ${ }^{3}$ It is necessary to maintain the condition that is ideal for cell repair and regeneration during the wound healing. Collagen production, angiogenesis, and granulation have important role in healing process. For its optimization, effective therapies using wound healing agents are required. ${ }^{5,7,31}$ Of which, hydrogels have been proposed as strong drug delivery media for acute open wound management due to their high content of water, biocompatibility, and flexibility. 5,26

In this present study, we used gel formulation of B. racemosa extract for open wound treatment on rat models. Our data suggest the extract with a concentration of $7 \mathrm{ppm}$ could accelerate the wound healing progress and is not inferior to 
Metcovazin. This suggests wound healing properties of phytocompounds contained in the B. racemosa extract. Previously, a study found that aqueous extract of B. racemosa contains diterpenes, triterpenoids, flavonoids, steroids and saponins. ${ }^{12}$ Saponins, in animal models, have been known to improve immune system, optimize blood sugar levels and reduce blood clots. ${ }^{32}$ Saponins also contribute to induce collagen production in skin fibroblasts via phosphorylation of Smad 2 protein. ${ }^{33}$ Furthermore, antioxidant and antibacterial properties of saponins could assist faster wound healing. ${ }^{34}$ Other than saponins, flavonoids have been reported to increase collagen secretion and consequently induce tissue granulation. ${ }^{13}$ Studies also prove that flavonoids have anti-inflammatory properties. ${ }^{35,36}$

Tannins also play a role in the wound healing process since they could act as astringents. ${ }^{37}$ Astringent causes reduced mucosal permeability, leading to stronger bonds between the mucosa which inhibits the entrance of microorganisms and irritant chemicals. ${ }^{34,38}$ Furthermore, tannins are reported to be capable of inhibiting hypersecretion of mucosal fluid and neutralizing inflammatory proteins. ${ }^{39}$ Tannin compounds promote antibacterial activities by hampering the permeability the bacterial cell wall. ${ }^{40}$ Wound healing properties are also possessed by terpenoids contained in $B$. racemosa extract including antimicrobial, antifungal, antiviral, antiparasitic, antihyperglycemic, antiallergenic, anti-inflammatory, antispasmodic, immuno-modulatory, and chemotherapeutic properties. ${ }^{14,15}$

Wound healing activities of plants from family Lecythidaceae have been reported by previous studies. ${ }^{16,17}$ Wound contraction of $125-140 \%$ was obtained after the treatment using topical treatment of Napoleona vogelii leaf extract. ${ }^{16}$ Topical administration of Barringtonia acutangula fruit as much as $20 \%$ w/w yielded $86.3 \%$ recovery after 14 days of treatment. ${ }^{17}$ Those stated results could not be compared to our study because of the use of different assessment method. Nonetheless, we argued that DESIGN scoring could provide more comprehensive assessment as it includes observations on wound depth, exudate secretion, wound size, infection, granulation, and necrotic tissue. As a limitation, this study was unable to identify the compound responsible for the healing properties. Therefore, further studies were required to figure out the bioactive compounds contained in the B. racemosa extract.

\section{Conclusions}

B. racemosa extract in gel formulation was effective for wound treatments in rat models. A formulation with $B$. racemosa extract concentration as low as $3 \mathrm{ppm}$ could exhibit the recovery rate similar to that obtained from those treated with Metcovazin. In animals treated with gel formulation of $7 \mathrm{ppm}$, the DESIGN score reached 0 sooner than that treated with Metcovazin. Taken together, gel formulation of $B$. racemosa extract is potentially be used to treat wound since it accelerates the wound healing process. In addition, gel as a delivery medium was found suitable for the $B$. racemosa extract.

\section{Data availability}

Underlying data

figshare: Acceleration of wound healing by topical application of gel formulation of Barringtonia racemosa (L.) Spreng kernel extract. https://doi.org/10.6084/m9.figshare.17256023.v6. ${ }^{41}$

This project contains the following file:

- Master.xlsx (DESIGN scores from 0 - 15 for all groups)

Data are available under the terms of the Creative Commons Attribution 4.0 International license (CC-BY 4.0).

\section{Reporting guidelines}

ARRIVE Essential 10 checklist for 'Acceleration of wound healing by topical application of gel formulation of Barringtonia racemosa (L.) Spreng kernel extract’. https://doi.org/10.6084/m9.figshare.18866303. ${ }^{42}$

Data are available under the terms of the Creative Commons Attribution 4.0 International license (CC-BY 4.0).

\section{Acknowledgments}

Authors would like to pay gratitude to the Rector of Universitas Sumatera Utara (USU). 
1. Brunauer A, Verboket RD, Kainz DM, et al.: Rapid Detection of Pathogens in Wound Exudate via Nucleic Acid Lateral Flow Immunoassay. Biosensors (Basel). 2021 Mar 6; 11(3): 74. PubMed Abstract | Publisher Full Text | Free Full Text

2. Merlino J, Gray T, Beresford R, et al.: Wound infection caused by Neisseria zoodegmatis, a zoonotic pathogen: a case report. Access Microbiol. 2021 Mar; 3(3): 000196. Epub 2021/06/22. PubMed Abstract | Free Full Text

3. Velnar T, Bailey T, Smrkolj V: The wound healing process: an overview of the cellular and molecular mechanisms. J. Int. Med. Res. 2009 Sep-Oct; 37(5): 1528-1542.

PubMed Abstract | Publisher Full Text

4. Kondo T, Ishida Y: Molecular pathology of wound healing. Forensic Sci. Int. 2010 Dec 15; 203(1-3): 93-98.

PubMed Abstract | Publisher Full Text

5. Liang $Y$, He J, Guo B: Functional Hydrogels as Wound Dressing to Enhance Wound Healing. ACS Nano. 2021 Aug; 15: 12687-12722. PubMed Abstract | Publisher Full Text

6. Shedoeva A, Leavesley D, Upton Z, et al.: Wound Healing and the Use of Medicinal Plants. Evid. Based Complement. Alternat. Med. 2019; 2019: 2684108-2684130.

PubMed Abstract | Publisher Full Text | Free Full Text

7. Yazarlu O, Iranshahi M, Kashani HRK, et al.: Perspective on the application of medicinal plants and natural products in wound healing: A mechanistic review. Pharmacol. Res. 2021 Aug 174; 174: 105841. Epub 2021/08/23.

PubMed Abstract | Publisher Full Text

8. Purnama A, Mardina V, Puspita K, et al.: Molecular docking of two cytotoxic compounds from Calotropis gigantea leaves against therapeutic molecular target of pancreatic cancer. Narra J. 2021; 1(2).

Publisher Full Text

9. Boakye YD, Agyare C, Ayande GP, et al.: Assessment of WoundHealing Properties of Medicinal Plants: The Case of Phyllanthus muellerianus. Front. Pharmacol. 2018; 9: 945.

PubMed Abstract | Publisher Full Text | Free Full Text

10. Lordani TVA, de Lara CE, FBP F, et al.: Therapeutic Effects of Medicinal Plants on Cutaneous Wound Healing in Humans: A Systematic Review. Mediat. Inflamm. 2018; 2018: 7354250. Epub 2018/05/29.

PubMed Abstract | Publisher Full Text | Free Full Text

11. Moeini $A$, Pedram $P$, Makvandi $P$, et al.: Wound healing and antimicrobial effect of active secondary metabolites in chitosan-based wound dressings: A review. Carbohydr. Polym 2020 Apr; 233(233): 115839. Epub 2020/02/16. PubMed Abstract | Publisher Full Text

12. Ho IYM, Abdul Aziz A, Mat JS: Evaluation of Anti-proliferative Effects of Barringtonia racemosa and Gallic Acid on Caco-2 Cells. Sci. Rep. 2020 Jun 19; 10(1): 9987 PubMed Abstract | Publisher Full Text | Free Full Text

13. Van QTT, Vien LT, Hanh TTH, et al.: Acylated flavonoid glycosides from Barringtonia racemosa. Nat. Prod. Res. 2020 May; 34(9): 1276-1281

PubMed Abstract | Publisher Full Text

14. Khan S, Jabbar A, Hasan CM, et al.: Antibacterial activity of Barringtonia racemosa. Fitoterapia. 2001; 72(2): 162-164. PubMed Abstract | Publisher Full Text

15. Deraniyagala SA, Ratnasooriya WD, Goonasekara CL Antinociceptive effect and toxicological study of the aqueous bark extract of Barringtonia racemosa on rats.J. Ethnopharmacol. 2003; 86(1): 21-26.

PubMed Abstract | Publisher Full Text

16. Adiele LC, Adiele RC, Enye JC: Wound healing effect of methanolic leaf extract of Napoleona vogelii (Family: Lecythidaceae) in rats. Asian Pac. J. Trop. Med. 2014; 7(8): 620-624. PubMed Abstract | Publisher Full Text

17. Mohanty A, Rath D, Prusty SK, et al.: Evaluation of wound healing potential of aqueous extract of Barringtonia acutangula fruit in rats with bacterial infection. International Journal of Pharmacy and Technology. 2016; 8(1): 10425-10432.

18. Liu K, Abdullah AA, Huang M, et al.: Novel Approach to Classify Plants Based on Metabolite-Content Similarity. Biomed. Res. Int 2017; 2017: 1-12.

PubMed Abstract | Publisher Full Text | Free Full Text

19. Sami $D$, Heiba $H$, Abdellatif $A$ : Wound healing models: A systematic review of animal and non-animal models. Wound Medicine. 2019; 24(1): 8-17. Publisher Full Text

20. Dorsett-Martin WA: Rat models of skin wound healing: a review. Wound Repair Regen. 2004 Nov-Dec; 12(6): 591-599. PubMed Abstract | Publisher Full Text
21. Zhang XG, Li XM, Zhou XX, et al.: The Wound Healing Effect of Callicarpa nudiflora in Scalded Rats. Evid. Based Complement. Alternat. Med. 2019; 2019: 1860680. Epub 2019/06/13. PubMed Abstract | Publisher Full Text | Free Full Text

22. Santos TS, Santos I, Pereira-Filho RN, et al.: Histological Evidence of Wound Healing Improvement in Rats Treated with Oral Administration of Hydroalcoholic Extract of Vitis labrusca. Curr. Issues Mol. Biol. 2021 Jun 11; 43(1): 335-352.

PubMed Abstract | Publisher Full Text

23. Karim S, Alkreathy HM, Ahmad A, et al.: Effects of Methanolic Extract Based-Gel From Saudi Pomegranate Peels With Enhanced Healing Potential on Excision Wounds in Diabetic Rats. Front. Pharmacol. 2021; 12: 704503. Epub 2021/06/15. PubMed Abstract | Publisher Full Text | Free Full Text

24. Bardaa S, Makni K, Boudaouara O, et al.: Development and Evaluation of the Wound Healing Effect of a Novel Topical Cream Formula Based on Ginkgo biloba Extract on Wounds in Diabetic Rats. Biomed. Res. Int. 2021; 2021: 1-12. PubMed Abstract | Publisher Full Text | Free Full Text

25. Corso M, Perreau F, Mouille G, et al.: Specialized phenolic compounds in seeds: structures, functions, and regulations. Plant Sci. 2020 Jul; 296: 110471. Epub 2020/06/17. PubMed Abstract | Publisher Full Text

26. Harrison IP, Spada F: Hydrogels for Atopic Dermatitis and Wound Management: A Superior Drug Delivery Vehicle. Pharmaceutics. 2018 Jun 14; 10(2): 71

PubMed Abstract | Publisher Full Text | Free Full Text

27. Joao De Masi EC, Campos AC, Joao De Masi FD, et al.: The influence of growth factors on skin wound healing in rats. Braz. J. Otorhinolaryngol. 2016 Sep-Oct; 82(5): 512-521. PubMed Abstract | Publisher Full Text

28. Assar DH, Elhabashi N, Mokhbatly AA, et al.: Wound healing potential of licorice extract in rat model: Antioxidants, histopathological, immunohistochemical and gene expression evidences. Biomed. Pharmacother. 2021 Nov; 143: 112151. Epub 2021/09/11

PubMed Abstract | Publisher Full Text

29. Smith AJ, Clutton RE, Lilley E, et al.: PREPARE: guidelines for planning animal research and testing. Lab. Anim. 2018 Apr; 52(2): 135-141.

PubMed Abstract | Publisher Full Text | Free Full Text

30. Federer W: Experimental design, theory and application. New Delhi: Oxford and IBH Publ. Co; 1967.

31. Tripodo G, Trapani A, Rosato A, et al.: Hydrogels for biomedical applications from glycol chitosan and PEG diglycidyl ether exhibit pro-angiogenic and antibacterial activity. Carbohydr. Polym. 2018 Oct 15; 198: 124-130.

PubMed Abstract | Publisher Full Text

32. Olas B, Urbanska K, Brys M: Saponins as Modulators of the Blood Coagulation System and Perspectives Regarding Their Use in the Prevention of Venous Thromboembolic Incidents. Molecules. 2020 Nov 6; 25(21): 5171. Epub 2020/11/12.

PubMed Abstract | Publisher Full Text | Free Full Text

33. Lee J, Jung $\mathrm{E}$, Lee J, et al.: Panax ginseng induces human Type $\mathrm{I}$ collagen synthesis through activation of Smad signaling. J. Ethnopharmacol. 2007 Jan 3; 109(1): 29-34. PubMed Abstract | Publisher Full Text

34. Asumang P, Boakye YD, Agana TA, et al.: Antimicrobial, antioxidant and wound healing activities of methanol leaf extract of Bridelia micrantha (Hochst.) Baill. Scientific African. 2021; 14: e00980. Publisher Full Text

35. Purnama A, Mardina V, Puspita K, et al.: Molecular docking of two cytotoxic compounds from Calotropis gigantea leaves against therapeutic molecular target of pancreatic cancer. Narra J. 2021. 1(2): e37. Publisher Full Text

36. Hasballah K, Sarong M, Rusly R, et al.: Antiproliferative Activity of Triterpenoid and Steroid Compounds from Ethyl Acetate Extract of Calotropis gigantea Root Bark against P388 Murine Leukemia Cell Lines. Sci. Pharm. 2021; 89(2): 21. Publisher Full Text

37. Wu W, Zhu QG, Wang WQ, et al.: Molecular basis of the formation and removal of fruit astringency. Food Chem. 2021 Sep 27; 372: 131234. Epub 2021/10/08. PubMed Abstract | Publisher Full Text

38. Pandey $\mathrm{P}$, Seo $\mathrm{HH}$, Kim H-I, et al.: Enhanced anti-ageing and wound healing properties of Ficus religiosa $\mathrm{L}$. bark, leaf and aerial root extract in human keratinocytes cell line (HaCaT). Vegetos. 2020; 33(1): 158-165. Publisher Full Text 
39. Ninan N, Forget A, Shastri VP, et al.: Antibacterial and AntiInflammatory pH-Responsive Tannic Acid-Carboxylated Agarose Composite Hydrogels for Wound Healing. ACS Appl. Mater. Interfaces. 2016 Oct 26; 8(42): 28511-28521.

PubMed Abstract | Publisher Full Text

40. Farha AK, Yang Q-Q, Kim G, et al.: Tannins as an alternative to antibiotics. Food Biosci. 2020; 38: 100751.

Publisher Full Text
41. Sitohang NA: Acceleration of wound healing by topical application of gel formulation of Barringtonia racemosa (L.) Spreng kernel extract. figshare. Dataset. 2021. Publisher Full Text

42. Sitohang NA: Acceleration of wound healing by topical application of gel formulation of Barringtonia racemosa (L.) Spreng kernel extract. figshare. Journal Contribution. 2022. Publisher Full Text 


\section{Open Peer Review}

\section{Current Peer Review Status: ? ?}

\section{Version 1}

Reviewer Report 08 March 2022

https://doi.org/10.5256/f1000research.114838.r123769

(C) 2022 Tallei T. This is an open access peer review report distributed under the terms of the Creative Commons Attribution License, which permits unrestricted use, distribution, and reproduction in any medium, provided the original work is properly cited.

\section{Trina Ekawati Tallei}

Department of Biology, Faculty of Mathematics and Natural Sciences, Sam Ratulangi University, Manado, Indonesia

I would like to comment on the study design. It has been previously published elsewhere but the authors did not cite it. ${ }^{1}$

The authors did not mention how many replications they made for each concentration (ppm).

The discussion should be expanded including supposition of what compounds (not groups of compounds) that play a role in wound healing which is supported by the literature. The group of compounds alone is still too general. The author should also discuss the mechanism of the wound healing process and relate it to their findings.

Authors should also discuss the use of DESIGN scoring, as compared to previous studies using the same method.

Authors are advised to describe the clinical application of the findings, advantages, and disadvantages.

\section{References}

1. Sitohang NA, Putra EDA, Musman M, Kamil H: Formulation and Evaluation of Gel Containing BarringtoniaRacemosa L.Spreng Kernel Extract for Topical Application. Proceedings of the International Conference on Health Informatics and Medical Application Technology. 2020. Reference Source

Is the work clearly and accurately presented and does it cite the current literature? Yes

Is the study design appropriate and is the work technically sound? Partly 
Are sufficient details of methods and analysis provided to allow replication by others? Yes

If applicable, is the statistical analysis and its interpretation appropriate?

I cannot comment. A qualified statistician is required.

Are all the source data underlying the results available to ensure full reproducibility? Partly

Are the conclusions drawn adequately supported by the results?

Yes

Competing Interests: No competing interests were disclosed.

Reviewer Expertise: Drug discovery and pharmacoinformatics.

I confirm that I have read this submission and believe that I have an appropriate level of expertise to confirm that it is of an acceptable scientific standard, however I have significant reservations, as outlined above.

Author Response 12 Mar 2022

Musri Musman

1. The previous publication only reports on the preparation of the gel formulation and its characteristics. It has been cited in the Methods.

2. The number of replications is based on the number of samples per group ( 4 rats $=4$ replications for each concentration).

3. As of now, there are only two compounds successfully isolated from the seed of $B$. racemosa; barringtogenol and barringtogenic acid. Hence, other than the two compounds, we could only provide general group of compounds.

4. We have tried our best searching DESIGN scoring in in vivo study, but still could not find the comparable study.

5. Yes, we agree that information about the clinical application, advantages, and disadvantages should be added. We have added such information at the end of the discussion.

Competing Interests: No competing interests were disclosed. 
(C) 2022 Emran T. This is an open access peer review report distributed under the terms of the Creative Commons Attribution License, which permits unrestricted use, distribution, and reproduction in any medium, provided the original work is properly cited.

\section{Talha Bin Emran}

Department of Pharmacy, BGC Trust University Bangladesh, Chittagong, Bangladesh

Title: Acceleration of wound healing by topical application of gel formulation of Barringtonia racemosa (L.) Spreng kernel extract

\section{Minor comments:}

Although the article has scientific rigor, several minor flows need to be improved before indexing.

1. The abstract section is unsuitable-no focus point in the abstract section.

2. Aim of the study need to write as the last paragraph of the introduction.

3. DESIGN scoring system: Any references?

4. Statistical analysis: Need some details.

5. On day 11 , the DESIGN scores were significantly different between the $7 \mathrm{ppm}$ group and positive control group ( $p=0.0286$, Mann-Whitney test) suggesting that $B$. racemosa extract with a concentration of $7 \mathrm{ppm}$ in gel formulation could assist better wound healing than Metcovazin. Is this enough to conclude?

6. The discussion is feeble. Please, include the data from other sources about related works.

7. Figures presentation are good.

8. Figure legends are self-explanatory.

9. The conclusion needs to address future perspectives.

Is the work clearly and accurately presented and does it cite the current literature? Yes

Is the study design appropriate and is the work technically sound?

Yes

Are sufficient details of methods and analysis provided to allow replication by others? Yes

If applicable, is the statistical analysis and its interpretation appropriate? Yes

Are all the source data underlying the results available to ensure full reproducibility? 
Yes

Are the conclusions drawn adequately supported by the results?

Yes

Competing Interests: No competing interests were disclosed.

Reviewer Expertise: Natural Product Chemistry, Immunology

I confirm that I have read this submission and believe that I have an appropriate level of expertise to confirm that it is of an acceptable scientific standard, however I have significant reservations, as outlined above.

Author Response 12 Mar 2022

Musri Musman

1. We have added more information, especially in the results part, to give readers clearer understanding on the study.

2. We have added the objective of the study in the last paragraph of the introduction, where it aimed to investigate the wound healing effect of $B$. racemosa extract in an animal model

3. There is a reference for DESIGN score. (Horn et al. Adv Skin Wound Care. 2015; 28:560-72.) This reference has been cited in the text.

4. The statistical analysis has been revised.

5. We agree with the reviewer. However, the data are sufficient to conclude that at least $B$. racemosa extract $7 \mathrm{ppm}$ has a similar wound healing property to that of Metcovazin (in vivo).

6. The data have been compared with those from family Lecythidaceae. The data could not be compared quantitatively because other studies did not use the DESIGN score. This explanation has been added in the last paragraph of the discussion.

7. We have revised the conclusions by adding the probably future studies of employing $B$. racemosa extract in treating a diabetic wound

Competing Interests: No competing interests were disclosed. 
The benefits of publishing with F1000Research:

- Your article is published within days, with no editorial bias

- You can publish traditional articles, null/negative results, case reports, data notes and more

- The peer review process is transparent and collaborative

- Your article is indexed in PubMed after passing peer review

- Dedicated customer support at every stage

For pre-submission enquiries, contact research@f1000.com 